\title{
Seasonality of Earnings Momentum in an Emerging Market: The Taiwan Experiences
}

\author{
Hsiao-Peng $\mathrm{Fu}^{1}$ \\ ${ }^{1}$ Department of Finance, Providence University, Taiwan, R.O.C. \\ Correspondence: Hsiao-Peng Fu, Department of Finance, Providence University, 200, Section 7, Taiwan Boulevard \\ Road, Shalu District, Taichung 43301, Taiwan, R.O.C. Tel: 886-4-2632-8001 Ext. 13614. E-mail: hspefu@pu.edu.tw
}

Received: December 7, 2013

Accepted: December 17, 2013

Online Published: January 10, 2014

doi:10.5430/ijfr.v5n1p71

URL: http://dx.doi.org/10.5430/ijfr.v5n1p71

\begin{abstract}
In Taiwan, firms are requested to announce earnings for the first and fourth quarters within one and four months, respectively, after the fiscal quarters' end. I therefore conjecture that prior to formal announcement, private earnings information have longer time to dissiminate for the fourth quarter than the first quarter, based on the gradual-diffusion-information model developed by Hong and Stein (1999). Furthermore, given the impact of earnings information on stock price, I hypothesize that returns after quarterly earnings announcement are higher for quarters having less time to disseminate private information before formal announcement than returns for quarters with more time. I uncover a pronounced seasonal pattern for post-announcement cumulative returns for hedge portfolios buying stocks having positive earnings surprises and selling stocks with negative earnings surprises, in accordance with the hypothesis. Specifically, cumulative returns for these hedge portfolios are significantly larger following the first quarter than the fourth quarter during the six to 12 months after the earnings announcement. The evidence is robust to risk adjustment. Moreover, this seasonality can be attributed more to the differential performance of stocks having positive earnings surprises than that of stocks having negative surprises. However, the seasonal results need to be explained with caution because the corresponding third quarter stock returns post-announcement are not as strong as those for the first quarters, despite the third quarter announcement also being made within one month after the fiscal quarter's end.
\end{abstract}

Keywords: earnings momentum, seasonality, emerging markets

\section{Introduction}

Since the pioneering work of Ball and Brown (1968), post earnings announcement drift (PEAD), or earnings momentum, has attracted strong interest. Most studies document the existence of this phenomenon, while some document its absence. Specifically, Bhattacharya et al. (2000) reported a lack of drift in the Mexican stock market. More importantly, they attribute its absence to the prevalence of insider trading throughout the market. That is, before earnings information is formally released, stock prices have already fully reacted to the information because of the information being privately spread in the investing community. Hong et al. (2003) provided similar evidence that earnings momentum estimated from analyst forecast revisions is weak for five Asian countries having relatively weak legal prohibitions of insider trading and/or relatively slack enforcement of such laws. The five countries are Taiwan, Malaysia, South Korea, Japan, and Singapore. Their results are consistent with gradual-information-diffusion model developed by Hong and Stein (1999), who argued that there are two categories of investors: newswatchers and momentum traders. Newswatchers trade only on private information, which gradually spreads across the investor community, creating underreaction dynamics. On the other hand, momentum investors trade exclusively on stock price momentum. In this paper, I focus on the gradual diffusion nature of private information, which indicates that private information requires a certain length of time to be fully incorporated into stock prices.

In the Taiwanese stock market, earnings for the first, second, third, and fourth quarters are, respectively, requested to be publicized by the end of the first, second, first, and fourth month subsequent to the end of the relevant fiscal quarter. (Note 1) Consequently, the interval between the fiscal quarter's end and the earnings announcement varies. According to the gradual-information-diffusion model, I conjecture that earnings momentum diminishes with the time length, because longer intervals before earnings news is publically disclosed provide more time for 
dissemination of private earnings information, and thereby less extent of information will be impounded into prices post announcement. Yet, it is difficult to determine the precise interval sufficient to allow stock prices to fully absorb private earnings information. The bottom line is that the first and third quarters are hypothesized to have stronger earnings momentum than the fourth quarter because the first and third quarters' requested announcement of earnings are nearest to the end of their fiscal quarters, whereas the fourth quarter has the longest interval.

Consistent with the above hypothesis, I identify a pronounced seasonal pattern for earnings momentum in Taiwan. Specifically, the cumulative returns for investment strategies involving purchase of good-news stocks and selling bad-news stocks are significantly larger for first quarters than fourth quarters for 6 to 12 months after the announcements. Furthermore, this evident seasonal variation retains its significance even after controlling for Fama-French's (1993) three risk factors or Carhart's (1997) four risk factors. Furthermore, this seasonal earnings momentum is more associated with the seasonal performance of good-news stocks than bad-news stocks. However, the seasonal results are weaker for third quarters despite the interval being the same as that for first quarters.

This research makes several contributions to the literature on earnings momentum or PEAD. First, in addition to uncovering Taiwanese experiences of a weak fourth-quarter phenomenon similar to that seen in the U.S. stock markets, this study discovers a strong first-quarter seasonality, which, to the best of my knowledge, has not yet been reported. The strong first quarter effect cannot be explained by the existing rationales for the U.S.'s weak fourth quarter effect, namely the tax-loss selling effect, (Note 2) underestimation of costs for non-fourth-quarter earnings, and the integral approach to quarterly earnings (see the next section for a review). Consequently, this analysis makes a further contribution by suggesting and partially confirming a market-specific rationale for the observed seasonality phenomenon: variant-regulated disclosure time. In addition, this study sheds further light on the gradual-information-diffusion theory in Hong and Stein (1999) and findings of sluggish spread of bad news compared to good news in Hong et al. (2000). Finally, contrary to Hong et al.'s (2003) discovery absence of PEAD in Taiwan, this analysis uncovers the existence of seasonally conditional earnings momentum.

The rest of this paper is structured as follows. The following section reviews related literature. Section 3 discusses data and methodology. Section 4 presents empirical results. Finally, section 5 offers concluding remarks.

\section{Related Literature}

On the basis of historical fundamental information (i.e., recently announced earnings), the existence of the PEAD anomaly, or earnings momentum, refutes the semi-strong efficiency hypothesis, thus becoming a well-known puzzle in financial economics because of its exceptional strong persistence relative to other anomalies (Fama, 1998). Ball and Brown (1968) first found stock prices move upwardly (downwardly) after the disclosure of positive (negative) annual earnings. Considerable subsequent research discovered identical drift following quarterly earnings announcements (e.g., Joy et al., 1977; Rendleman et al., 1982; Gennotte and Truemann, 1996). While the robustness of Ball and Brown's finding received widespread confirmation in the U.S. stock markets, its causes remained controversial (e.g., Foster et al., 1984; Bernard and Thomas, 1989, 1990; Ball, 1993). Early research focused on rational explanations such as failure of CAPM, market imperfections, or systematic research design error (see a review by Ball (1993)). Recent studies have concentrated on investors' incapability of interpreting information contained in recently announced earnings (Bernard and Thomas, 1990; Ball and Bartov, 1996; Rangan and Sloan, 1998; Soffer and Lys, 1999; Brown and Han, 2000). More recently, a number of psychological biases have been advocated to account for the drift, such as representativeness and conservatism (Barberis et al., 1998), overconfidence and biased self-attribution (Daniel et al., 1998), and the disposition effect (Frazzini, 2006). In addition, Chordia and Shivakumar (2006) asserted an association between earnings momentum and future macroeconomic growth. With respect to seasonality, some U.S. studies uncovered weaker drift post the fourth-quarter earnings because of factors such as the tax-loss selling effect (Lakonishok and Smidt, 1986), managers' discretion in underestimating costs for non-fourth-quarter earnings (Mendenhall and Nichols, 1988), or taking an integral approach to quarterly earnings (Rangan and Sloan, 1998), among others (Kama, 2009).

PEAD or earnings momentum has also been reported in some non-U.S. markets, for example, in countries as divergent as Australia, Canada, France, Germany, Hong Kong, and the U.K. (Alford et al., 1993; Amir et al., 1993; Chan and Seow, 1996; Liu et al., 2003; Su, 2003; Hong et al., 2003). Nevertheless, some other non-U.S. markets reveal no trace of the drift. Bhattacharya et al. (2000) and Hong et al. (2003) documented serious insider trading as the cause for this lack of PEAD or earnings momentum in Mexico, Malaysia, South Korea, Japan, Singapore, and Taiwan. Su (2003) showed absence of PEAD in B-share in China. In Taiwan, the empirical research has not produced definitive results. For example, Lin (1994) and Liu (1996) reported strong PEAD, yet Chiao (1995) showed only a weak phenomenon, as did Hong et al. (2003) in terms of earnings momentum mentioned previously. 


\section{Data and Methodology}

This study uses Taiwanese stock data complied by the Taiwan Economic Journal (TEJ) from June 1987 to December 2007. All non-financial common stocks listed on the Taiwan Stock Exchange (TWSE) are included. However, stocks priced below three New Taiwan dollars at the ranking date are discarded so as to eliminate potential biases stemming from illiquidity problems for small firms or from microstructure issues (e.g., bid-ask bounces) inherited from extremely low-priced securities (Hong et al., 2003).

Following the stylized procedures of earnings momentum research, securities are categorized into quintile portfolios according to standardized unexpected earnings (SUE) at the end of the announcement month, i.e., the portfolio formation date. SUE1 (SUE5) portfolios comprise the $20 \%$ of stocks with the lowest (highest) earnings surprises according to the most recently announced quarterly earnings (Chan et al., 1996).

In computing SUE, I utilize the common seasonal random walk model because it is found to fit well Taiwanese investors' expectation dynamics (Wu and Chao, 2001). SUE is estimated as follows:

$$
S U E_{i t}=\left(e_{i q}-e_{i q-4}\right) / \sigma_{i t},
$$

where $S U E_{i t}$ is SUE for security $i$ in formation month $t, e_{i q}$ is quarterly earnings announced most recently in formation month $t$ for security $i, e_{i q-4}$ is earnings from four quarters ago for security $i$, and $\sigma_{i t}$ is the standard deviation for $e_{i q}-e_{i q-4}$ over the previous two years.

After event month $t=0$, quintile portfolios are held for 12 months to observe mid-term performance after the announcement of earnings, i.e., holding periods are months $t+1, \ldots, t+12$. Portfolio returns consist of the value-weighted returns of component stocks. This weighting mechanize is widely used in Asian studies because firms in Asian markets are relatively smaller than those in developed markets, implying that the illiquidity problem is relatively more serious (Chui et al., 2003). Because of the overlapping holding periods, I use Newey-West $t$ statistics to correct for heteroskedasticity and autocorrelation. Table 1 presents summary statistics for SUEs in each calendar quarter for quintile portfolios. Apparently, the number of firms commencing to be listed on TWSE monotonically increases from the first quarters to the fourth quarters. As a result, firm-quarter observations are largest for fourth quarters, while the number of sample quarters in this analysis remains constant for each of the four calendar quarters.

Table 1. Descriptive statistics for SUE by calendar quarters and quintile portfolios

\begin{tabular}{|c|c|c|c|c|c|c|c|c|}
\hline Quarter & Portfolio & Firm-Quarter & Mean & Min. & 10 Pctl. & 50 Pctl. & 90 Pctl. & Max. \\
\hline \multirow[t]{5}{*}{ Q1 } & 1(Low) & 940 & -1.17 & -1.82 & -1.77 & -0.98 & -0.64 & -0.54 \\
\hline & 2 & 940 & -0.40 & -0.90 & -0.74 & -0.32 & -0.08 & -0.02 \\
\hline & 3 & 940 & -0.08 & -0.42 & -0.32 & -0.05 & 0.21 & 0.23 \\
\hline & 4 & 940 & 0.23 & -0.06 & -0.01 & 0.21 & 0.58 & 0.63 \\
\hline & 5(High) & 941 & 0.90 & 0.28 & 0.50 & 0.85 & 1.34 & 1.45 \\
\hline \multirow[t]{5}{*}{ Q2 } & 1(Low) & 968 & -1.45 & -3.44 & -1.82 & -1.47 & -0.76 & -0.67 \\
\hline & 2 & 968 & -0.53 & -1.44 & -0.78 & -0.44 & -0.21 & -0.17 \\
\hline & 3 & 968 & -0.10 & -0.57 & -0.36 & -0.11 & 0.18 & 0.22 \\
\hline & 4 & 968 & 0.31 & -0.06 & -0.01 & 0.33 & 0.59 & 0.93 \\
\hline & 5(High) & 965 & 1.03 & 0.52 & 0.53 & 1.04 & 1.47 & 2.09 \\
\hline \multirow[t]{5}{*}{ Q3 } & 1 (Low) & 972 & -1.23 & -2.68 & -2.08 & -1.11 & -0.69 & -0.63 \\
\hline & 2 & 972 & -0.46 & -1.22 & -0.94 & -0.36 & -0.14 & -0.11 \\
\hline & 3 & 972 & -0.10 & -0.46 & -0.44 & -0.03 & 0.13 & 0.16 \\
\hline & 4 & 972 & 0.25 & -0.09 & -0.05 & 0.30 & 0.50 & 0.56 \\
\hline & 5(High) & 976 & 0.97 & 0.31 & 0.57 & 1.00 & 1.32 & 1.82 \\
\hline \multirow[t]{5}{*}{ Q4 } & 1(Low) & 1041 & -1.53 & -2.96 & -2.18 & -1.25 & -1.05 & -0.87 \\
\hline & 2 & 1041 & -0.59 & -1.23 & -1.03 & -0.48 & -0.22 & -0.13 \\
\hline & 3 & 1041 & -0.13 & -0.58 & -0.42 & -0.08 & 0.16 & 0.27 \\
\hline & 4 & 1041 & 0.34 & -0.03 & 0.02 & 0.34 & 0.65 & 0.85 \\
\hline & 5(High) & 1038 & 1.30 & 0.69 & 0.76 & 1.27 & 1.78 & 2.03 \\
\hline
\end{tabular}

\section{Empirical Results}

\subsection{Cumulative Returns on Hedge Portfolios by Calendar Quarter}

To preserve as many observations as possible, I estimate $t$-values for each of the four quarters by regressing cumulative returns on hedge portfolios for all four quarters on four dummy variables, with each denoting one calendar quarter with no intercept. Furthermore, the $t$-statistics for return difference between each of the three 
quarters and the fourth quarters are obtained by regressing hedge portfolio returns for all four quarters on intercept and three dummy variables representing the first, second, and third quarters. Consistent with the hypothesis, Table 2 reports that the economic magnitude of cumulative returns on hedge portfolios post the earnings announcement for first quarters are the highest out of all the four quarters for 10 out of the 12 holding-month periods, a result having statistical significance from month $t+4$ onward. By contrast, the fourth quarters' cumulative returns are persistently lowest, with negative values throughout the 12 months. As a result, the return differences between the two calendar quarters are significant between months $t+6$ and $t+12$. Note that although the third quarters' cumulative returns possess similar economic magnitude as the first quarters' returns in some periods, they are generally lower in both economic magnitude and statistical significance than first quarters' cumulative returns. Furthermore, as expected, second quarters have cumulative returns normally lower than those of the first and third quarters, but higher than those of the fourth quarters. Figure 1 depicts hedge portfolios' cumulative return dynamics by calendar quarter.

Table 2. Cumulative returns on hedge portfolios by calendar quarters

\begin{tabular}{|c|c|c|c|c|c|c|c|c|c|}
\hline$(t+1: t+n)$ & Q1 & & $\mathrm{Q} 2$ & Q3 & $\mathrm{Q} 4$ & $\mathrm{Q} 1-\mathrm{Q}$ & & Q2 - Q4 & Q3 - Q4 \\
\hline \multirow[t]{2}{*}{$\mathrm{n}=1$} & 0.94 & & 0.79 & 1.49 & -0.09 & 1.03 & & $\begin{array}{l}0.87 \\
\end{array}$ & $\begin{array}{l}1.58 \\
\end{array}$ \\
\hline & $(0.72)$ & & $(0.62)$ & $(0.76)$ & $(-0.08)$ & $(0.62)$ & & $(0.54)$ & $(0.71)$ \\
\hline \multirow[t]{2}{*}{2} & 1.04 & & 0.92 & 5.11 & -2.25 & 3.29 & & 3.17 & 7.36 \\
\hline & $(0.35)$ & & $(0.68)$ & (1.91) & $(-0.91)$ & $(0.85)$ & & (1.13) & $(2.00) * *$ \\
\hline \multirow[t]{2}{*}{3} & 5.29 & & 2.83 & 4.70 & -2.04 & 7.33 & & 4.87 & 6.74 \\
\hline & (1.57) & & (1.40) & (1.60) & $(-0.63)$ & (1.56) & & $(1.27)$ & (1.51) \\
\hline \multirow[t]{2}{*}{4} & 5.43 & & 4.47 & 2.51 & -0.04 & 5.46 & & 4.51 & 2.55 \\
\hline & (1.90) & * & $(2.27) *$ & $(0.81)$ & $(-0.01)$ & $(1.27)$ & & $(1.20)$ & $(0.57)$ \\
\hline \multirow[t]{2}{*}{5} & 6.95 & & 4.81 & 2.50 & -0.59 & 7.54 & & 5.40 & 3.09 \\
\hline & (2.39) & ** & $(1.68) *$ & $(0.68)$ & $(-0.16)$ & (1.60) & & (1.16) & $(0.59)$ \\
\hline \multirow[t]{2}{*}{6} & 8.08 & & 1.97 & 4.09 & -0.98 & 9.06 & & 2.95 & 5.07 \\
\hline & (2.38) & ** & $(0.69)$ & (1.31) & $(-0.23)$ & $(1.68)$ & * & $(0.58)$ & $(0.96)$ \\
\hline \multirow[t]{2}{*}{7} & 8.83 & & 2.43 & 4.30 & -2.08 & 10.92 & & 4.52 & 6.38 \\
\hline & (2.82) & *** & $(0.79)$ & (1.38) & $(-0.47)$ & (2.02) & ** & $(0.84)$ & (1.18) \\
\hline \multirow[t]{2}{*}{8} & 9.77 & & 1.57 & 3.71 & -3.00 & 12.77 & & 4.57 & 6.71 \\
\hline & (2.88) & *** & $(0.51)$ & $(1.05)$ & $(-0.68)$ & (2.30) & ** & $(0.85)$ & (1.18) \\
\hline \multirow[t]{2}{*}{9} & 8.88 & & 1.39 & 3.30 & -2.95 & 11.83 & & 4.34 & 6.25 \\
\hline & (2.53) & ** & $(0.44)$ & $(0.81)$ & $(-0.70)$ & (2.15) & ** & $(0.82)$ & (1.07) \\
\hline \multirow[t]{2}{*}{10} & 7.13 & & 2.07 & 5.64 & -4.41 & 11.54 & & 6.47 & 10.04 \\
\hline & (1.90) & * & $(0.67)$ & (1.38) & $(-0.92)$ & (1.90) & * & (1.13) & (1.62) \\
\hline \multirow[t]{2}{*}{11} & 6.72 & & 0.30 & 4.46 & -4.15 & 10.86 & & 4.45 & 8.61 \\
\hline & (1.98) & * & $(0.08)$ & $(1.08)$ & $(-0.85)$ & (1.83) & * & $(0.71)$ & (1.37) \\
\hline \multirow[t]{2}{*}{12} & 5.52 & & 1.10 & 5.22 & -4.61 & 10.13 & & 5.71 & 9.83 \\
\hline & $(1.87)$ & * & $(0.28)$ & $(1.22)$ & $(-1.03)$ & (1.89) & * & $(0.96)$ & (1.61) \\
\hline
\end{tabular}

$* * *, * *$, and $*$ denote significant levels of $1 \%, 5 \%$, and $10 \%$, respectively.

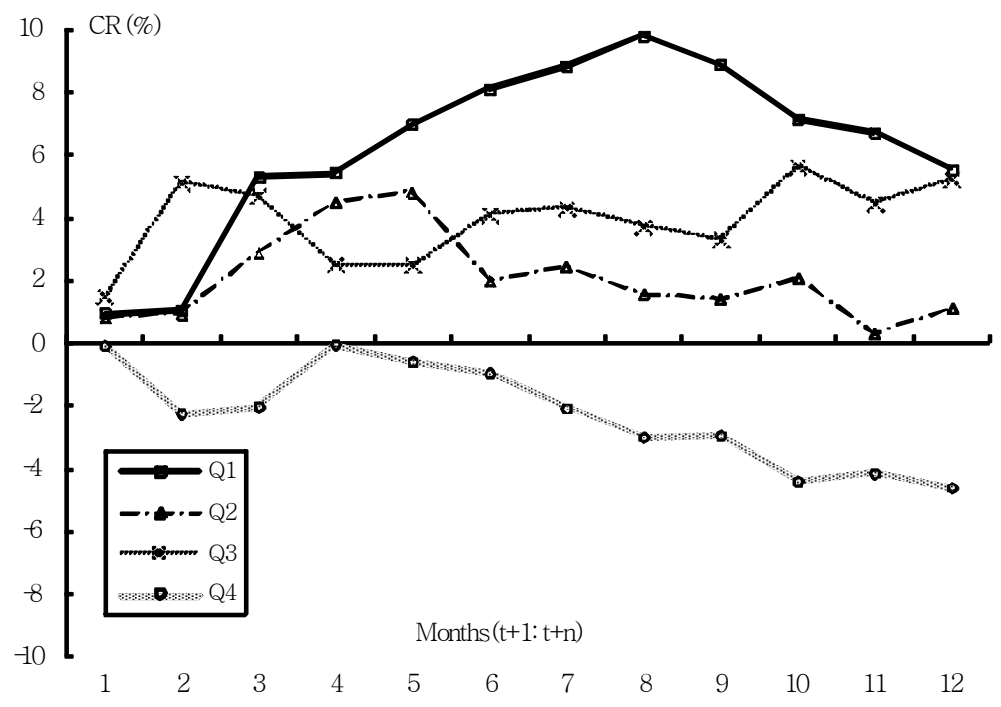

Figure 1. Cumulative returns on arbitrage portfolios 


\subsection{Cumulative Returns Conditional on Risks}

To determine if the observed strong seasonality is attributable to risk factors, I then estimate risk-adjusted cumulative returns according to the three factor model of Fama-French (1993) and the four factor model of Carhart (1997). Following Cooper et al. (2004), I first estimate factor loadings for each holding month $t+\mathrm{n}$, where $n=1,2, \ldots, 12$, by running regression equations for the two models, respectively, with hedge portfolios' returns as dependent variables. Second, I compute risk-adjusted returns for each holding month from equation (2) below, and finally, construct cumulative risk-adjusted returns by summing up risk-adjusted returns of holding months.

$$
\operatorname{Adj}_{t+n}=R_{t+n}-\sum \beta_{i t+n} f_{i}
$$

Here $A d j R_{t^{+n} n}$ and $R_{t+\mathrm{n}}$ denote monthly risk-adjusted and raw returns on hedge portfolios in holding month $t+\mathrm{n} ; \beta_{i t+\mathrm{n}}$ is the estimated loading for factor $i$ in holding month $t+\mathrm{n}$ (where the summation in equation (2) is for $i$ ); and $f_{i}$ is the realization of factor $i$. The three factors in Fama-French (1993) are market risk premium, small firm premium (or SMB), and value firm premium (or HML). The three factors plus price momentum variable (or UMD) constitude the four factors in Carhart (1997).

Tables 3 and 4 document that the strength of seasonal earnings momentum survives the risk adjustment. Furthermore, the statistical significance for differential cumulative returns between the first and fourth quarters over months $t+10$ to $t+12$ increases from the original 10\% significance level for raw returns to a $5 \%$ significance level after controlling for Fama-French's three factors or Carhart's four factors. In addition, the counterpart raw return difference between the third and fourth quarters strengthens from no significance to marginal significance for returns adjusted with Carhart's factors. Figure 2 shows cumulative returns on hedge portfolios with adjustment of Carhart's (1997) four factors.

Table 3. Fama-French's three-factor adjusted cumulative returns on hedge portfolios

\begin{tabular}{|c|c|c|c|c|c|c|c|c|c|c|}
\hline$(t+1: t+n)$ & Q1 & & Q2 & & Q3 & Q4 & Q1 - Q & & $\overline{\mathrm{Q} 2-\mathrm{Q} 4}$ & $\overline{\mathrm{Q} 3-\mathrm{Q} 4}$ \\
\hline \multirow[t]{2}{*}{$\mathrm{n}=1$} & 1.12 & & 0.84 & & 1.36 & 0.13 & 1.00 & & 0.71 & 1.23 \\
\hline & $(0.84)$ & & $(0.63)$ & & $(0.73)$ & $(0.12)$ & $(0.58)$ & & $(0.42)$ & $(0.57)$ \\
\hline \multirow[t]{2}{*}{2} & 1.40 & & 1.23 & & 3.91 & -1.87 & 3.26 & & 3.10 & 5.78 \\
\hline & $(0.47)$ & & $(0.78)$ & & (1.52) & $(-0.77)$ & $(0.85)$ & & (1.08) & (1.62) \\
\hline \multirow[t]{2}{*}{3} & 5.46 & & 2.80 & & 3.78 & -1.70 & 7.16 & & 4.50 & 5.48 \\
\hline & (1.61) & & (1.07) & & (1.41) & $(-0.53)$ & $(1.53)$ & & (1.08) & (1.28) \\
\hline \multirow[t]{2}{*}{4} & 5.38 & & 4.12 & & 2.44 & -0.21 & 5.60 & & 4.33 & 2.65 \\
\hline & (1.93) & ** & $(2.27)$ & ** & $(0.89)$ & $(-0.07)$ & $(1.36)$ & & (1.23) & $(0.64)$ \\
\hline \multirow[t]{2}{*}{5} & 6.84 & & 4.80 & & 3.11 & -0.97 & 7.81 & & 5.77 & 4.08 \\
\hline & (2.39) & ** & (1.73) & * & $(0.96)$ & $(-0.29)$ & $(1.76)$ & * & (1.31) & $(0.86)$ \\
\hline \multirow[t]{2}{*}{6} & 7.98 & & 2.85 & & 4.77 & -1.09 & 9.07 & & 3.94 & 5.86 \\
\hline & (2.49) & ** & $(1.02)$ & & (1.66) & $(-0.30)$ & (1.87) & * & $(0.86)$ & $(1.22)$ \\
\hline \multirow[t]{2}{*}{7} & 9.27 & & 3.50 & & 4.70 & -1.65 & 10.92 & & 5.15 & 6.35 \\
\hline & (2.97) & ** & (1.17) & & $(1.79) *$ & $(-0.42)$ & (2.19) & ** & (1.05) & (1.31) \\
\hline \multirow[t]{2}{*}{8} & 9.91 & & 2.79 & & 3.57 & -2.43 & 12.33 & & 5.21 & 6.00 \\
\hline & (3.24) & ** & $(0.93)$ & & $(1.22)$ & $(-0.62)$ & $(2.48)$ & $* *$ & (1.06) & (1.18) \\
\hline \multirow[t]{2}{*}{9} & 9.67 & & 1.84 & & 3.62 & -1.89 & 11.56 & & 3.72 & 5.51 \\
\hline & $(2.80)$ & ** & $(0.61)$ & & $(0.99)$ & $(-0.50)$ & $(2.25)$ & ** & $(0.77)$ & (1.01) \\
\hline \multirow[t]{2}{*}{10} & 8.97 & & 1.66 & & 5.54 & -2.48 & 11.45 & & 4.14 & 8.02 \\
\hline & (2.39) & ** & $(0.56)$ & & (1.59) & $(-0.58)$ & $(2.00)$ & ** & $(0.79)$ & (1.42) \\
\hline \multirow[t]{2}{*}{11} & 8.89 & & 0.06 & & 3.75 & -1.92 & 10.81 & & 1.97 & 5.66 \\
\hline & (2.72) & $* * *$ & $(0.02)$ & & (1.09) & $(-0.44)$ & (1.99) & ** & $(0.35)$ & (1.01) \\
\hline \multirow[t]{2}{*}{12} & 7.71 & & 0.50 & & 4.74 & -2.53 & 10.24 & & 3.03 & 7.27 \\
\hline & $(2.56)$ & ** & $(0.15)$ & & $(1.21)$ & $(-0.63)$ & (2.05) & $* *$ & $(0.58)$ & (1.28) \\
\hline
\end{tabular}

$* * *, * *$, and $*$ denote significant levels of $1 \%, 5 \%$, and $10 \%$, respectively. 
Table 4. Carhart's four-factor adjusted cumulative returns on hedge portfolios

\begin{tabular}{|c|c|c|c|c|c|c|c|c|c|c|c|c|}
\hline$(t+1: t+n)$ & Q1 & & Q2 & & Q3 & & Q4 & Q1 - Q & & Q2-Q4 & $\mathrm{Q} 3-\mathrm{Q}$ & \\
\hline \multirow[t]{2}{*}{$\mathrm{n}=1$} & 0.95 & & 1.26 & & 1.34 & & 0.16 & 0.79 & & 1.10 & 1.18 & \\
\hline & $(0.69)$ & & $(1.40)$ & & $(0.70)$ & & $(0.13)$ & $(0.42)$ & & $(0.71)$ & $(0.52)$ & \\
\hline \multirow[t]{2}{*}{2} & 1.31 & & 1.77 & & 3.85 & & -1.77 & 3.08 & & 3.54 & 5.62 & \\
\hline & $(0.44)$ & & (1.19) & & (1.51) & & $(-0.71)$ & $(0.80)$ & & $(1.22)$ & (1.57) & \\
\hline \multirow[t]{2}{*}{3} & 4.43 & & 3.30 & & 4.27 & & -2.29 & 6.72 & & 5.59 & 6.56 & \\
\hline & (1.32) & & (1.24) & & (1.71) & $*$ & $(-0.69)$ & (1.43) & & (1.32) & (1.56) & \\
\hline \multirow[t]{2}{*}{4} & 4.39 & & 4.09 & & 3.34 & & -1.19 & 5.57 & & 5.28 & 4.53 & \\
\hline & $(1.55)$ & & $(2.27)$ & $* *$ & (1.34) & & $(-0.38)$ & $(1.32)$ & & (1.47) & (1.11) & \\
\hline \multirow[t]{2}{*}{5} & 5.83 & & 4.75 & & 4.02 & & -1.95 & 7.78 & & 6.71 & 5.98 & \\
\hline & (2.02) & $* *$ & $(1.72)$ & $*$ & (1.38) & & $(-0.55)$ & (1.71) & * & $(1.50)$ & (1.29) & \\
\hline \multirow[t]{2}{*}{6} & 6.92 & & 3.02 & & 5.74 & & -2.13 & 9.05 & & 5.15 & 7.87 & \\
\hline & (2.18) & $* *$ & $(1.08)$ & & (2.17) & $* *$ & $(-0.58)$ & (1.86) & * & (1.11) & (1.68) & * \\
\hline \multirow[t]{2}{*}{7} & 8.24 & & 3.69 & & 5.65 & & -2.66 & 10.90 & & 6.35 & 8.31 & \\
\hline & (2.68) & $* * *$ & $(1.22)$ & & $(2.31)$ & $* *$ & $(-0.68)$ & (2.18) & $* *$ & (1.28) & (1.75) & * \\
\hline \multirow[t]{2}{*}{8} & 8.89 & & 3.00 & & 4.52 & & -3.43 & 12.31 & & 6.42 & 7.95 & \\
\hline & (2.88) & $* * *$ & $(0.98)$ & & (1.61) & & $(-0.86)$ & $(2.43)$ & $* *$ & $(1.28)$ & (1.57) & \\
\hline \multirow[t]{2}{*}{9} & 8.52 & & 2.04 & & 4.75 & & -3.07 & 11.59 & & 5.11 & 7.82 & \\
\hline & $(2.47)$ & $* *$ & $(0.69)$ & & (1.30) & & $(-0.79)$ & $(2.23)$ & $* *$ & $(1.05)$ & (1.43) & \\
\hline \multirow[t]{2}{*}{10} & 7.32 & & 1.95 & & 7.05 & & -4.05 & 11.37 & & 6.00 & 11.10 & \\
\hline & (2.07) & $* *$ & $(0.72)$ & & (2.14) & $* *$ & $(-0.97)$ & $(2.08)$ & $* *$ & $(1.20)$ & $(2.05)$ & $* *$ \\
\hline \multirow[t]{2}{*}{11} & 7.45 & & 1.17 & & 5.33 & & -3.41 & 10.86 & & 4.58 & 8.74 & \\
\hline & $(2.41)$ & $* *$ & $(0.41)$ & & (1.59) & & $(-0.81)$ & $(2.08)$ & $* *$ & $(0.90)$ & (1.61) & \\
\hline \multirow[t]{2}{*}{12} & 6.45 & & 1.12 & & 6.18 & & -3.87 & 10.32 & & 4.99 & 10.05 & \\
\hline & $(2.12)$ & $* *$ & $(0.39)$ & & (1.69) & $*$ & $(-0.96)$ & $(2.05)$ & $* *$ & $(1.01)$ & $(1.82)$ & $*$ \\
\hline
\end{tabular}

$* * *, * *$, and $*$ denote significant levels of $1 \%, 5 \%$, and $10 \%$, respectively.

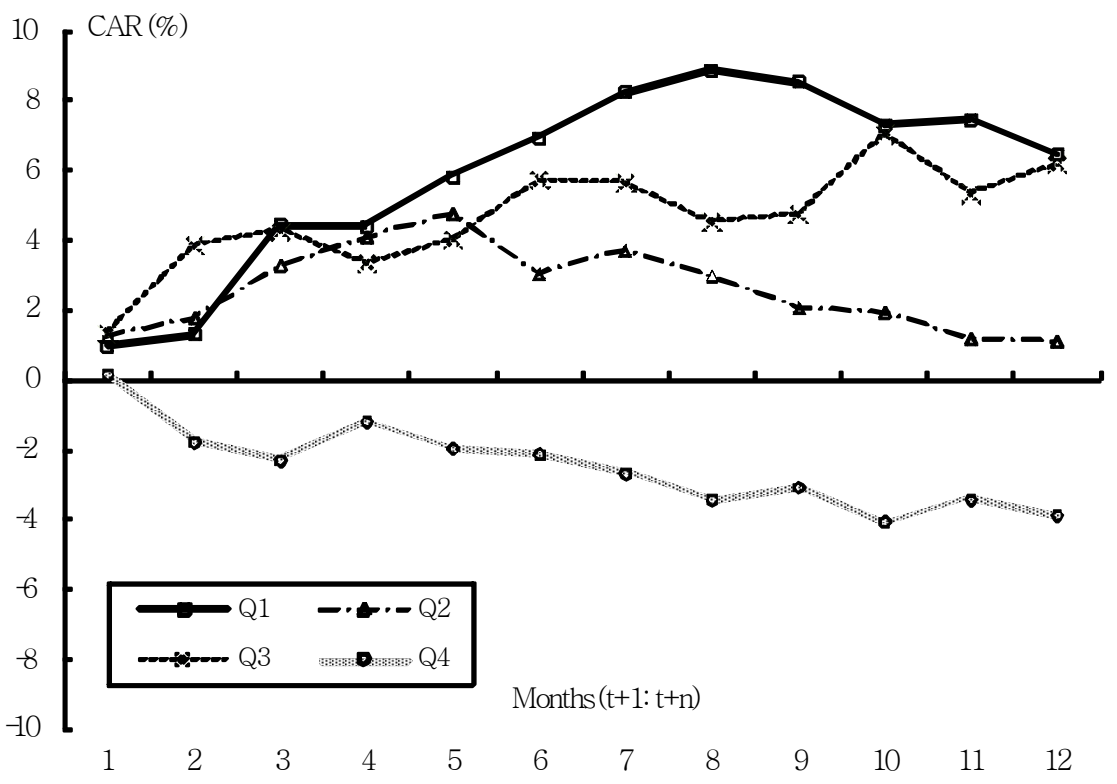

Figure 2. Cumulative abnormal returns for arbitrage portfolios with risk-adjustment of Carhart's four factors

\subsection{Cumulative Returns for Negative versus Positive Earnings Surprise Portfolios}

Extending the gradual-information-diffusion model in Hong and Stein (1999), Hong et al. (2000) uncovered that bad earnings news diffuses more slowly than good earnings news. The implication of Hong et al.'s findings for this analysis is (1) if the four-month period for the fourth quarters is sufficiently long for private information of good earnings to disseminate, (2) yet the one-month period for first quarters is not sufficient for the same level of 
dissemination, and (3) neither period is sufficiently long for bad news to fully disseminate, then the seasonal differential performance observed post the earnings announcement can be expected to be more attributable to differential performance of good-news stocks than that of bad-news stocks. Conversely, the differential performance can be largely associated with the performance of bad-news stocks if the one-month period is sufficient (so is the four-month period) for private good information to thoroughly disseminate, but the four-month period is not sufficient (nor the one-month period) for bad news to spread. Furthermore, both good and bad private information may need longer than four months to disseminate, resulting in both good-news and bad-news stocks showing performances connected to the seasonal earnings momentum. In summary, either of the cases can be true since it is hard to determine how fast bad/good earnings information will travel across the investor community as mentioned previously.

Table 5 indicates that the proportion of differential cumulative returns (on hedge portfolios) between the first and fourth quarters that can be explained by differential cumulative returns on positive-surprise stocks ranges from $50 \%$ to $113 \%$ (see column (9)). Conversely, the counterpart proportion that can be interpreted by differential returns on negative-surprise stocks has a maximum of $50 \%$, with most below this level (i.e., the absolute value of the percentage shown in column (5)). Accordingly, the economic magnitude of the explained proportion is larger for stocks with positive earnings surprises. This finding implies that the one-month period appears insufficient for complete diffusion of good news, which instead seems to be incorporated into stock prices more thoroughly over the four-month period.

Table 5. Cumulative returns on SUR1 versus SUR5 portfolios

\begin{tabular}{|c|c|c|c|c|c|c|c|c|}
\hline (1) & (2) & (3) & $(4)=(2)-(3)$ & $(5)=(4) /($ SUE5-SUE1) & (6) & (7) & $(8)=(6)-(7)$ & $(9)=(8) /($ SUE5-SUE1 $)$ \\
\hline$(t+1: t+n)$ & Q1 & Q4 & Q1 - Q4 & \% of (SUE5-SUE1) & Q1 & Q4 & Q1 - Q4 & $\%$ of (SUE5-SUE1) \\
\hline$n$ & \multicolumn{4}{|c|}{ SUE1(Negative earnings surprises) } & \multicolumn{4}{|c|}{ SUE5(Positive earnings surprises) } \\
\hline \multirow[t]{2}{*}{1} & -2.25 & -2.11 & -0.14 & $-13 \%$ & -1.31 & -2.20 & 0.89 & $87 \%$ \\
\hline & $(-1.44)$ & $(-1.50)$ & $(-0.06)$ & & $(-0.74)$ & $(-1.83)$ & $(0.42)$ & \\
\hline \multirow[t]{2}{*}{2} & -3.29 & -2.71 & -0.58 & $-18 \%$ & -2.24 & -4.96 & 2.71 & $82 \%$ \\
\hline & $(-0.89)$ & $(-0.64)$ & $(-0.10)$ & & $(-0.76)$ & $(-1.79)$ & $(0.67)$ & \\
\hline \multirow[t]{2}{*}{3} & -4.50 & -2.84 & -1.66 & $-23 \%$ & 0.79 & -4.88 & 5.67 & $77 \%$ \\
\hline & $(-1.02)$ & $(-0.65)$ & $(-0.27)$ & & $(0.24)$ & $(-2.03)$ & $(1.37)$ & \\
\hline \multirow[t]{2}{*}{4} & -5.62 & -6.13 & 0.50 & $9 \%$ & -0.20 & -6.17 & 5.97 & $109 \%$ \\
\hline & $(-1.00)$ & $(-1.15)$ & $(0.06)$ & & $(-0.04)$ & $(-1.43)$ & $(0.85)$ & \\
\hline \multirow[t]{2}{*}{5} & -9.19 & -10.19 & 0.99 & $13 \%$ & -2.25 & -10.78 & 8.53 & $113 \%$ \\
\hline & $(-1.25)$ & $(-1.44)$ & $(0.10)$ & & $(-0.31)$ & $(-1.86)$ & $(0.92)$ & \\
\hline \multirow[t]{2}{*}{6} & -10.99 & -9.10 & -1.90 & $-21 \%$ & -2.91 & -10.07 & 7.16 & $79 \%$ \\
\hline & $(-1.92)$ & $(-1.60)$ & $(-0.23)$ & & $(-0.50)$ & $(-2.12)$ & $(0.95)$ & \\
\hline \multirow[t]{2}{*}{7} & -7.78 & -4.52 & -3.26 & $-30 \%$ & 1.06 & -6.60 & 7.66 & $70 \%$ \\
\hline & $(-1.35)$ & $(-0.83)$ & $(-0.41)$ & & $(0.18)$ & $(-1.47)$ & (1.02) & \\
\hline \multirow[t]{2}{*}{8} & -5.98 & 0.40 & -6.38 & $-50 \%$ & 3.79 & -2.60 & 6.39 & $50 \%$ \\
\hline & $(-1.07)$ & $(0.08)$ & $(-0.83)$ & & $(0.71)$ & $(-0.45)$ & $(0.81)$ & \\
\hline \multirow[t]{2}{*}{9} & -0.35 & 4.22 & -4.57 & $-39 \%$ & 8.53 & 1.27 & 7.26 & $61 \%$ \\
\hline & $(-0.08)$ & $(1.05)$ & $(-0.79)$ & & (1.69) & $(0.31)$ & (1.12) & \\
\hline \multirow[t]{2}{*}{10} & 5.47 & 8.61 & -3.14 & $-27 \%$ & 12.60 & 4.20 & 8.40 & $73 \%$ \\
\hline & $(0.98)$ & $(1.76)$ & $(-0.42)$ & & $(2.29)$ & $(1.20)$ & $(1.28)$ & \\
\hline \multirow[t]{2}{*}{11} & 8.57 & 11.21 & -2.64 & $-24 \%$ & 15.29 & 7.06 & 8.22 & $76 \%$ \\
\hline & (1.53) & $(2.40)$ & $(-0.36)$ & & $(2.90)$ & $(2.19)$ & $(1.33)$ & \\
\hline \multirow[t]{2}{*}{12} & 8.42 & 9.72 & -1.30 & $-13 \%$ & 13.94 & 5.12 & 8.83 & $87 \%$ \\
\hline & $(1.26)$ & $(1.92)$ & $(-0.16)$ & & $(2.15)$ & $(1.22)$ & $(1.14)$ & \\
\hline
\end{tabular}

\section{Conclusions}

Taiwan's stock market has a distinct feature that the deadline requested to publicize quarterly earnings varies across calendar quarters. In particular, first, second, third, and fourth quarters' earnings have to be disclosed by the end of one, two, one, and four months, respectively, following the relevant fiscal quarter. According to the gradual-information-diffuse model of Hong and Stein (1999), the time difference means that private information regarding quarterly earnings may have different time intervals to disseminate throughout the investing community before the formal announcement date. As a result, I hypothesize that return dynamics after formal announcement show sensitivity to the time interval because it reflects varied lengths of time for private information to be incorporated into stock prices. Using data from the Taiwanese stock market covering the years 1987-2007, I uncover 
a pronounced seasonal pattern for post-announcement cumulative returns on hedge portfolios buying stocks with positive earnings surprises and selling stocks with negative earnings surprises, which is consistent with the hypothesis. Specifically, hedge portfolios exhibit significantly larger cumulative returns for first quarters than fourth quarters for 6 to 12 months after the earnings announcement. This significant difference survives risk adjustment of both the three factors in Fama-French (1993) and the four factors in Carhart (1997). Moreover, the observed seasonality is attributable more to differential performance of stocks with positive earnings surprises than those with negative earnings surprises. However, the seasonal results need to be received with caution because the corresponding stock returns post the third quarter announcement are not as strong as those for the first quarter, despite the third quarter's earnings announcement also being made within one month after the fiscal quarter's end.

\section{Acknowledgements}

The author thanks seminar participants at the 2009 Asian Finance Association Conference for their helpful comments. The author acknowledges financial support from Providence University (Project No. PU97-11100-B19).

\section{References}

Alford, A., Jones, J., Leftwish, R., \& Zmijewski, M. (1993). The relative informativeness of accounting disclosures in different countries. Journal of Accounting Research, 31, 183-223. http://dx.doi.org/10.2307/2491170

Amir, E., Harris, T., \& Venuti, E. (1993). A comparison of the value-relevance of U.S. versus non-U.S. GAAP accounting measures using form 20-F reconciliations. Journal of Accounting Research, 31, 230-264. http://dx.doi.org/10.2307/2491172

Ball, R. (1992). The earnings-price anomaly. Journal of Accounting and Economics, 15, 319-345. http://dx.doi.org/10.2307/2491172

Ball, R., \& Bartov, E. (1996). How naïve is the stock market's use of earnings information? Journal of Accounting and Economics, 21, 319-337. http://dx.doi.org/10.1016/0165-4101(96)00420-X

Ball, R., \& Brown, P. (1968). An empirical evaluation of accounting income numbers. Journal of Accounting Research, 6, 159-178. http://dx.doi.org/10.2307/2491172

Barberis, N., Shleifer, A., \& Vishny, R. (1998). A model of investor sentiment. Journal of Financial Economics, 49, 307-343. http://dx.doi.org/10.1016/S0304-405X(98)00027-0

Bernard, V. (1993). Stock price reaction to earnings announcements: A summary of recent anomalous evidence and possible explanations. In R.H. Thaler (Ed.), Advances in Behavioral Finance. Russell Sage Foundation: New York.

Bernard, V., \& Thomas, J. (1989). Post-earnings drift: delayed price response or risk premium? Journal of Accounting Research, 27, 1-36. http://dx.doi.org/10.2307/2491062

Bernard, V., \& Thomas, J. (1990). Evidence that stock prices do not fully reflect the implications of current earnings for future earnings. Journal of Accounting and Economics, 13, 305-340. http://dx.doi.org/10.1016/0165-4101(90)90008-R

Bhatttacharya, U., Daouk, H., Jorgenson, B., \& Kehr, C.-H. (2000). When an event is not an event: the curious case of an emerging market. Journal of Financial Economics, 55, 69-101. http://dx.doi.org/10.1016/S0304-405X(99)00045-8

Blume, M., \& Stambaugh, R. (1983). Biases in computed returns: an application to the size effect. Journal of Financial Economics, 12, 387-404.

Brown, L., \& Han, J. (2000). Do stock prices reflect the implications of current earnings for future earnings for AR1 firms? Journal of Accounting Research, 149-164. http://dx.doi.org/10.2307/2672926

Carlton, D., \& Fischel, D. (1983). The regulation of insider trading. Stanford Law Review, 35, 857-895. http://dx.doi.org/10.2307/1228706

Chan, K., \& Seow, G. (1996). The association between stock returns and the foreign GAAP earnings versus earnings adjusted to U.S. GAAP. Journal of Accounting and Economics, 21, 139-158. http://dx.doi.org/10.1016/0165-4101(95)00405-X

Chan, L.K.C., Jegadeesh, N., \& Lakonishok, J. (1996) Momentum strategies. Journal of Finance, 51, 1681-1713. http://dx.doi.org/10.1111/j.1540-6261.1996.tb05222.x

Chen, G.-M., Kim, K., Nofsinger, J., \& Rui, O. (2007). Trading performance, disposition effect, overconfidence, 
representativeness bias, and experience of emerging market investors. Unpublished working paper. State University of New York at Buffalo.

Chui, A., Titman, S., \& Wei, J. (2003). Momentum, legal systems and ownership structure: an analysis of Asian stock markets. Unpublished working paper. University of Texas at Austin.

Cooper, M., Gutierrez Jr., R., \& Hameed, A. (2004). Market states and momentum. Journal of Finance, 59, 1345-1365. http://dx.doi.org/10.1111/j.1540-6261.2004.00665.x

Daniel, K., Hirshleifer, D., \& Subrahmanyam, A. (1998). Investor psychology and security market under-and overreactions. Journal of Finance, 53(6), 1839-1886. http://dx.doi.org/10.1111/0022-1082.00077

Fama, E. (1998). Market efficiency, long-tem returns, and behavioral finance. Journal of Financial Economics, 49, 283-306. http://dx.doi.org/10.1016/S0304-405X(98)00026-9

Fama, F., \& French, K. (1993). Common risk factors in the returns on stocks and bonds. Journal of Financial Economics, 33, 3-56. http://dx.doi.org/10.1016/0304-405X(93)90023-5

Ferris, S., Haugen, R., \& Makhija, A. (1988). Predicting contemporary volume with historic volume at differential price levels: evidence supporting the disposition effect. Journal of Finance, 43, 677-697. http://dx.doi.org/10.1111/j.1540-6261.1988.tb04599.x

Foster, G., Olsen, C., \& Shevlin, T. (1984). Earnings releases, anomalies, and the behavior of security returns. The Accounting Review, 59, 574-603.

Frazzini, A. (2006). The disposition effect and the underreaction to news. Journal of Finance, 61(4), 2017-2046. http://dx.doi.org/10.1111/j.1540-6261.2006.00896.x

Gennotte, G., \& Truemann, B. (1996). The strategic timing of corporate disclosures. Review of Financial Studies, 9, 665-690. http://dx.doi.org/10.1093/rfs/9.2.665

Harvey, C., \& Siddique, A. (2000). Conditional skewness in Asset pricing tests. Journal of Finance, 55, 1263-1295. http://dx.doi.org/10.1111/0022-1082.00247

Hong, D., Lee, C., \& Swaminathan, B. (2003). Earnings momentum in international markets. Unpublished working paper. Cornell University.

Hong, H., \& Stein, J. C. (1999). A unified theory of underreaction, momentum trading, and overreaction in asset markets. Journal of Finance, 54, 2143-2184. http://dx.doi.org/10.1111/0022-1082.00184

Hong, H., Lim, T., \& Stein, J. C. (2000). Bad news travels slowly: Size, analyst coverage, and the profitability of momentum strategies. Journal of Finance, 55, 265-295. http://dx.doi.org/10.1111/0022-1082.00206

Hsu, K.-H., \& Lin, P.-W. (2005). A study on disposition effect of individual investors: empirical findings taking into account market valuations. Journal of Management, 22, 85-107.

Hsu, P.-C. (2005). The disposition effect in Taiwan. Taiwan Banking and Finance Quarterly, 6, 21-33.

Huang, C.-H., Liao, H.-M., \& Liao, Y.-X. (2004). Do stock prices fully reflect the implications of current earnings for future earnings for AR(1) firms in Taiwan? Journal of Contemporary Accounting, 5, 25-56.

Huang, H. (2005). The regulation of insider trading in China: a critical review and proposals for reform. Australian Journal of Corporate Law, 17, 281-322.

Jegadeesh, N., \& Titman, S. (1993). Returns to buying winners and selling losers: implications for stock market efficiency. Journal of Finance, 48, 65-91. http://dx.doi.org/10.1111/j.1540-6261.1993.tb04702.x

Jegadeesh, N., \& Titman, S. (2001). Profitability of momentum strategies: An evaluation of alternative explanations. Journal of Finance, 56, 699-720. http://dx.doi.org/10.1111/0022-1082.00342

Joy, O., Litzenberger, R., \& McEnally, R. (1977). The adjustment of stock prices to announcements of unanticipated changes in quarterly earnings. Journal of Accounting Research, 15, 207-225. http://dx.doi.org/10.2307/2490349

Kama, I. (2009). On the market reactions to revenue and earnings surprises. Journal of Business, Finance, and Accounting, 36, 31-50. http://dx.doi.org/10.1111/j.1468-5957.2008.02121.x

Lakonishok, J., \& Smidt, S. (1986). Volume for winners and losers: taxation and other motives for stock trading. Journal of Finance, 41, 951-974. http://dx.doi.org/10.1111/j.1540-6261.1986.tb04559.x

Lee, C., \& Swaminathan, B. (2000). Price momentum and trading volume. Journal of Finance, 55, 2017-2069. 
http://dx.doi.org/10.1111/0022-1082.00280

Liu, W., Strong, N., \& Xu, S. (2003). Post-earnings-announcement in the UK. European Financial Management, 9 , 89-116. http://dx.doi.org/10.1111/1468-036X.00209

Manne, H. (1966). Insider Trading and the Stock Market. Free Press, New York.

Mendenhall, R.R., \& Nichols, W.D. (1988). Bad news and differential market reactions to announcements of earlier-quarters versus fourth-quarter earnings. Journal of Accounting Research, 26, 63-86. http://dx.doi.org/10.2307/2491180

Moskowitz, T., \& Grinblatt, M. (1999). Do industries explain momentum? Journal of Finance, 54, 1249-1290. http://dx.doi.org/10.1111/0022-1082.00146

Odean, T. (1998). Are investors reluctant to realize their losses? Journal of Finance, 53, 1775-1798. http://dx.doi.org/10.1111/0022-1082.00072

Rangan, S., \& Sloan, R., (1998). Implications of the integral approach to quarterly reporting for the post-earnings-announcement drift. The Accounting Review, 71, 353-371.

Rendleman, Jr., R., Jones, C., \& Latane, H. (1982). Empirical anomalies based on unexpected earnings and the importance of risk adjustments. Journal of Financial Economics, 10, 269-287. http://dx.doi.org/10.1016/0304-405X(82)90003-4

Shu, P.-G., Yeh, Y.-H., Chiu, S.-B., \& Chen, H.-S. (2005). Are Taiwanese individual investors reluctant to realize their losses? Pacific-Basin Finance Journal, 13, 201-223. http://dx.doi.org/10.1016/j.pacfin.2004.08.001

Soffer, L., \& Lys, T., (1999). Post-earnings announcement drift and the dissemination of predictable information. Contemporary Accounting Research, 16, 305-331. http://dx.doi.org/10.1111/j.1911-3846.1999.tb00583.x

$\mathrm{Su}$, D. (2003). Stock price reactions to earnings announcements: evidence from Chinese markets. Review of Financial Economics, 12, 271-286. http://dx.doi.org/10.1016/S1058-3300(02)00085-X

Wu, T.-Z., \& Chao, Y.-Y. (2001). The efficiency of investors use of quarterly earnings information in the Taiwan Stock Exchange. Taiwan Accounting Review, 2, 85-114.

\section{Notes}

Note 1 . Starting 2012, quarterly earnings announcement deadlines have been changed to 45 days and three months after the end of fiscal quarters for the first three and fourth quarters, respectively.

Note 2. There is no capital gain tax in this market. 